during the summer of 1881 , has returned to Chicago, and has recommenced his valuable measures of double stars with the large refractor. The present report has an engraving of this instrument, and of the tower of the Dearborn Ob ervatory, in which it is mounted.

Comet i882 $b$ (Finlay, Septrmber 8).-The following positions of this comet are deluced from the elements published in NATURE last week :-

\section{At $\mathbf{1} 8 \mathrm{~h}$. Greenwich M.T.}

\begin{tabular}{|c|c|c|c|c|c|}
\hline . & & $\begin{array}{ll}\text { R.A. } \\
\text { m } & \text { s. } \\
13 & 22\end{array}$ & & $\begin{array}{l}\text { Decl. } \\
-1_{5} \quad 7 \% 3\end{array}$ & 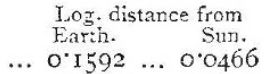 \\
\hline $21 \ldots$ & Io & ro 39 & $9 \ldots$ & I 5542 & $.0 .1613 \ldots 0.0640$ \\
\hline $23 \ldots$ & Io & 753 & $3 \ldots$ & I6 $40 \% 4$ & $\ldots 0.1633 \ldots 0.0804$ \\
\hline 25 & 10 & 53 & $3 \ldots$ & $17260^{\circ}$ & $\ldots 0.165$ I $\ldots 0.0959$ \\
\hline 27 & 10 & 28 & $8 . .$. & IS II O & $\ldots 0.1666 \ldots 0.1106$ \\
\hline $29 \ldots$ & 9 & 597 & $7 \ldots$ & I8 55.5 & $\begin{array}{lllll}\ldots & 0.1679 & \ldots & 0.1247\end{array}$ \\
\hline $3^{I}$ & 9 & 5559 & $9 \ldots$ & $-1939 \cdot 6$ & $\ldots 0.1690 \ldots 0.1382$ \\
\hline
\end{tabular}

\section{CHEMICAL NOTES}

MM. HaUtefeuille and Chappuis have obtained what appears to be pure liquid ezone, by compressing a mixture of oxygen and ozone at 125 atmospheres, and cooling the end of the capillary tube by a jet of liquid ethylene : on suddenly releasing the pressure, a drop of a very deep indigo-blue liquid remained in the end of the tube. The gas above this liquid was colourless, but as the last traces of liquid evaporated, the gas was seen to have a blue colour (Compt. rend. xciv. 1249).

IT is well known that sulphuretted hydrogen produces little or no precipitate in an aqueous solution of arsenious oxide : according to the experiments of Messrs. H. Schulze (Fournal fiir pract. Chemie, 2, xxv. 43I), such a liquid contains a colluidal form of arsenious sulphide. This colloid may be completely separated from dissolved arsenious oxide by prolonged dialysis the solution, if dilute, is scarcely changed by long-continued boiling; the presence of free acids or of such soluble salt; as chloride of potassium, iron, or chromium induces a change of the colloidal into an insoluble form of arsenious sulphide.

By strongly compressing phosphoretted hydrogen in prezence of water, and then suddenly decreasing the pressure, $M$. Cailletet has obtained a crystalline hydrate of this compound, the existence of which is conditioned by the temperature and pressure; the critical point, i.e. the temperature above which the substance cannot exist, whatever be the pressure, is $28^{\circ}$. Hydrates of sulphuretted hydrogen and of ammonia have also been obtained by this method (Compt. rend., xcv. 58).

By a somewhat similar process, $M$. Wroblewski has obtained a solid crystalline hydrate of carbon dioxide, $\mathrm{CO}_{2} .8 \mathrm{H}_{2} \mathrm{O}$ : the experimental results of this author seem to show that at the pressure required to cause the absorption of carbon dioxide by water in the proportion indicated by the formula $\mathrm{CO}_{2} . \mathrm{H}_{2} \mathrm{O}$, the water would be entirely frozen, and therefore that this hydrate cannot be obtained by this method (Compt rend., xciv, I355).

" WHEN solution of two salts, capable of mutual action, are mixed, the solution contains four salts": it has hitherto been difficult to give a direct experimental proof of this generalisation made half a century ago by Berthelot. In the last number of the Berichte of the German Chemical Society ( 15,1840 ) Herr Briigelmann describes the following experiments designed to prove the justness of Berthelot's statement:-Equal volumes of cold saturated solutions of cobalt chloride and nickel sulphate are mixed and allowed to deposit crystals by evaporation at ordinary temperatures; the crystals contain cobalt and nickel, but combined with sulphuric acid only. A mixture of solution of cobalt chloride and copper sulphate, prepared similarly to the preceding, deposits sulphate of the two metals almost free from chlorides. Copper sulphate and potassium dichromate solutions when mixed deposit crystals consisting almost entirely of sulphates of copper and potassium, the second crop of crystal; contain a little chromate of the two metals, and the final crop is nearly free from sulphates.

THE "Compagnie Generale des Cyanures et Produits Chimiques" of Paris have issued a small pamphlet explanatory of the various technical applications of the salts known as sulphocyanates, which can be now readily manufactured in a state of purity. Sulphocyanate of aluminium is used as a mordant in alizarine dyeing; s'lphocyanate of copper in the preparation of aniline black, and also, along with potassium chlorate and antimony sulphide, in the preparation of matches; sulphocyanate of potassium may be employed as a refrigerating material, as during the solution of $\mathbf{I} 30$ parts of this salt in Ioo parts of water, temperature is lowered through $34^{\circ}$; sulpho-cyanate of ammonium is more effectual, weight for weight, as an antichlor, than hyposulphite of soda.

Investigations conducted at the Baden Aniline and Soda Works show that the change of orthonitrophenyl propiolic acid into indigo, which (as already explained in this journal) has been for the most part effected by grapes or with sugar, can al:o be produced by the agency of sulphides, suiphydrates, polysulphides, thiocarbonates, and especially the alkaline xanthates (Chemisches Centralblatt, 1882, 366).

\section{GEOGRAPHICAL NOTES}

News has been received from the expedition of Dr. Emil Riebeck, dated July 7 last. It will be remembered that Dr. Riebeck, together with Dr. Schweinfurth made a thorough investigation of the island of Socotra, which was of high scientific importance. After this task was accomplished, the travellers separated, and 1)r. Riebeck crossed to Bombay, travelled through large tracts of the Himalaya Mountains, remained for some time in Cashmere, then passed through the Ganges land, investioated Ceylon, and eventually undertook a special and detailed examination of the coast district of Aracan. He ascended the Karnasuli River from Tschittagong as far as the Hill tribes, to which Prof. Bastian has drawn special attention. He made many measurements, took numerous photographs and plaster casts of this highly interesting tribe, which is still living in a most primitive natural state. The climate, however, and particularly the frequent fording of rivers, soon told upon Dr. Riebeck's health. He contracted a fever, and had to be taken to Singapore. Hi; valuable collections of zoological, anthropological, and ethnological specimens duly attracted the attention of geographers, and were frequently referred to at the recent "Geographentag." Since then Dr. Riebeck has continued his journey. Starting from Singapore, he is to follow the eastern coast of the Asiatic continent, then to cross over to Aistralia and New Zealand, and finally to return to Europe next summer by way of San Francisco and Panama.

To the Berlin Geozraphical Society the other evening, Major von Mechow gave some account of his explorations during the last year or two in the region of the Coango. Leaving Berlin in September, 1878, accompanied by a ship's carpenter and a gardener, Major von Mechow arrived at Dundo on the Coanza in the following January; but, owing to varions difficulties, it was the beginning of 1880 before he could start northwards into the interior at the head of II 5 native carriers. Crossing and re-crossing the Cambo, and passing through various powerful and hospitable tribes, the German traveller, after a thirty-seven days' march, at last reached the Coango on July I9, I880, and, under the guidance of the great chief Tembo Aluma, visited the magnificent Succambondu waterfall, which he named after the Emperor William. After canoeing it on the Coango for twentyfive days, Major von Mechow made a detour to pay his respects to the great Muene Putu Kassongo, by whom he was received in great state, and returning on September $x 9$ to the river, he followed it to longitude 5 deg. 5 min., from which point the fear of his followers of the neighbouring cannibals compelled him to return. In forty-five days he again reached the abode of Kassongo, where he stayed some time, and at last arrived on February 20, 188 I, at Malange, where he met his returning countryman, Dr. Buchner, as well as Herr Pogge and Lieut. Wissmann, who were both starting on a similar tour of explo. ration.

A German edition of Amici's " Morocco" has been published by Hartleben of Vienna. Herr von Schweiger-Lerchenfeld is the editor, and has to a considerable extent remodelled the work, adding interesting ethnographical and historical notes, and omitting passages and references which in the original work can only interest Italian readers, on account of their purely private and local character. Its scientific value is also considerably increased. Two new chapters have been added, one on Southern Morocco, the other on the war between Spain and Morscco in 1860 , and these are not the least attractive ones in the book, quite apart from the geological interest attaching to 